\title{
Deposition and Mineralogical Characteristics of Atmospheric Dust in relation to Land Use and Land Cover Change in Delhi (India)
}

\author{
Bablu Kumar, Kopal Verma, and Umesh Kulshrestha \\ School of Environmental Sciences, Jawaharlal Nehru University, New Delhi 110067, India \\ Correspondence should be addressed to Umesh Kulshrestha; umeshkulshrestha@gmail.com
}

Received 30 May 2014; Revised 31 July 2014; Accepted 31 July 2014; Published 26 August 2014

Academic Editor: Jaime Hart

Copyright (c) 2014 Bablu Kumar et al. This is an open access article distributed under the Creative Commons Attribution License, which permits unrestricted use, distribution, and reproduction in any medium, provided the original work is properly cited.

\begin{abstract}
This study highlights that the increasing urbanization and industrialization in Delhi are responsible for higher fluxes of atmospheric dust and its chemical constituents. Delhi has experienced a drastic change in land use and land cover area during the past two decades. Road lengths of the city have increased by $76 \%$ from 1985 to 2011 . The number of mobile vehicles has reached $80,52,508$ in 2014 from 24,32,295 in 1994. The industrial units in Delhi have increased by 39.54\% in 2011 as compared to 1994 value. Atmospheric dust which is originated from soil in this region becomes carbon rich due to interaction of suspended soil with atmospheric pollutants. Emissions of carbonaceous aerosols from coal and petroleum combustions are mainly responsible for silica dominated soil dust transforming into carbon rich particulate matter. Such dust may play very important role in the atmosphere having significant influence on human health, global warming, climate change, radiative forcing, visibility, and cloud formation. It is expected that if the rate of development remains the same, green cover of the city invariably will be sized down in order to meet the demand of housing, transportation, industries, and so forth in proportion to the rising population.
\end{abstract}

\section{Introduction}

Generally, atmospheric dust represents airborne particles in the size range $<1 \mu \mathrm{m}$ to $\sim 75 \mu \mathrm{m}[1,2]$. Atmospheric mineral dust is mainly emitted from arid and dry regions followed by its transportation to distant places through high speed winds. In addition, open land, grazing fields, ploughing, vehicle use, and unpaved roads, and so forth, are also important sources of dust [3]. According to Jickells and coworkers (2005), around one-third of the global land area is considered a potential source of atmospheric dust [4]. Global distribution of atmospheric dust has been thoroughly modelled by Tegen and Fung $(1994 ; 1995)[5,6]$. The abundance of dust in the air is controlled by factors such as vegetation cover, precipitation, wind velocity, and soil moisture [7]. Dust mainly consists of loose particles contributed by soil erosion, road transport, industries, volcanic eruptions, and so forth.

The atmospheric mineral dust plays an important role in controlling various atmospheric processes such as radiative forcing, cloud characteristics, precipitation, and atmospheric chemistry [8,9]. Dust aerosols impact these processes according to their size distribution, origin, and lifetime in the atmosphere $[5,6,10-12]$. Mineral dust has significant influence on ecosystem, environment, and biogeochemical cycles through deposition of minerals and organic materials on terrestrial ecosystem $[4,13]$. Deposition of dust can affect the nutrient levels in aquatic system $[13,14]$. Also, it adversely affects human health when contaminated by carbonaceous materials, soluble and chelatable metallic salts, and pesticides $[15,16]$.

LULCC also plays an important role in dust emission. Mostly vegetation cover is reduced and built area is increased in urbanization processes. Due to rapid development, developing countries are facing drastic LULCC due to human activities. In the absence of integrated and holistic development in regional planning, developing countries are experiencing the problem of loss of agricultural land, open space, and protection of ecologically sensitive areas [17]. Development of peripheral or suburban areas near metropolitan cities is leading to sparse vegetation and encroachment on wetland 
and forests areas to fulfil the demand of infrastructure and industry for the growing population. In case of Delhi city, about $60 \%$ of agricultural land has been transformed into nonagricultural area resulting in decrease in net sown area from 85,000 ha to 46,000 ha [17]. The population of Delhi has reached 17,838,842in 2014 (increased by $29.4 \%$ from 2001 to 2014). Many researchers have studied land use and land cover changes particularly in urban areas [17-19]. Haphazard industrial development of Delhi and adjoining areas is also responsible for higher atmospheric dust and other environmental problems. As compared to 1994, the industrial units have increased by 39.54\% in 2011 in Delhi region [20]. Numbers of vehicles and road lengths have also increased in Delhi. Delhi had 24, 32,295 mobile vehicles in 1994 which has increased by $185 \%$ reaching to $69,32,706$ vehicles in 2010 [20]. According to recent data of Delhi Government (http://www.delhi.gov.in), a total of 80,52,508 vehicles are registered up to June 30,2014 . The road length of the city has increased by 76\% from 1985 to 2011 [20].

Delhi region has semiarid climate. Most of the time, dry weather conditions prevail which promote suspension of soil and road dust into the atmosphere. Ambient concentrations of reactive gases are controlled by continuous input of atmospheric dust contributed by suspended soil. Hence, dustfall deposition is a significant removal mechanism for acidic gases such as sulphur dioxide in India [21, 22]. Despite the evidences of ecological importance of dust deposition, the comprehensive studies on emission, deposition, and chemistry of dustfall have not been carried out in India. Hence, the present study has been conducted to measure the dustfall fluxes with the mineralogical, morphological, and elemental characteristics of airborne dust and local soil in relation to land use and land cover (LULC) change in Delhi.

\section{Materials and Methods}

2.1. Sampling Site. Sampling of atmospheric dust was carried out at the terrace of School of Environmental Science building which is located inside the campus of Jawaharlal Nehru University (JNU). As shown in Figure 1, JNU lies in south of Delhi $\left(28.38^{\circ} \mathrm{N}, 77.12^{\circ} \mathrm{E}\right)$. This figure also shows soil composition of Delhi city. The site represents urban background nature. The main sources of air pollution in Delhi are coal based thermal power plants, vehicular exhausts, various industries, and so forth. It is the fourth most polluted city in the world in terms of suspended particulate matter levels [23]. Delhi is the second most populated city in India having total population of $17,838,842$ in 2014 in around $1490 \mathrm{~km}^{2}$. The rocks of Delhi belong both to the earliest and to the latest chapters of the geological history of the earth, that is, the Precambrian and the Quaternary [24]. The Delhi ridge which is the northernmost extension of Aravalli mountain covering $35 \mathrm{~km}$ extends from southern parts of the territory to western bank of Yamuna [25]. The soils of Delhi area are mostly light with some fraction of medium texture soils. The light texture soils are represented by sandy, loamy, sand, and sandy loam, whereas medium texture soils are represented by loam silty loam. The thickness of the quaternary alluvium soil cover of

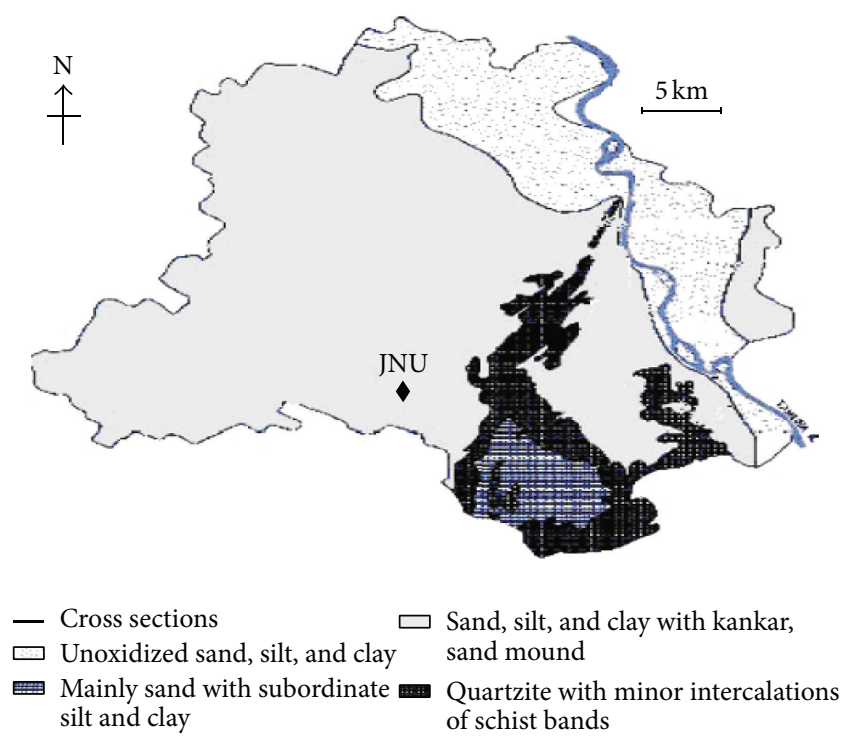

FIGURE 1: Geological map of Delhi [54].

Delhi in both the eastern and the western side of the ridge is variable from a few meters to about 300 meters.

\subsection{Samples Collection}

2.2.1. Dustfall Samples. A plastic tray of dimensions $(19.5 \mathrm{~cm} \times 23.5 \mathrm{~cm})$ was placed on the terrace of building, $\sim 2 \mathrm{~m}$ above the ground level during winter season from November 2013 to April 2014. Very similar method was used by Kulshrestha and coworkers (2003) [21]. After an exposure of 5 days the deposited dust was collected and weighed. The tray was thoroughly cleaned with high quality deionized water and dried before the collection of next samples. The amount of dustfall, area of the tray, and the period of dustfall collection were used to calculate deposition fluxes of dustfall. Samples were wrapped in aluminum foil and stored in refrigerator at $4^{\circ} \mathrm{C}$ before analysis by X-ray diffraction (XRD) and scanning electron microscope (SEM).

2.2.2. Soil Samples. Samples of surface soil were also collected in the vicinity of our school ( $\sim 1 \mathrm{~km}$ radius) from unperturbed area. Before collection, upper layer of soil containing plant roots and plant debris was removed carefully. The collected soil samples were taken in different polythene bags. Samples were then grinded and sieved first from 60 mesh and then from 200 mesh in order to attain a smooth and uniform texture. Grinded and sieved soil samples were stored in petri dishes which were then sealed with Al foil properly and stored in refrigerator at $4^{\circ} \mathrm{C}$ for analysis.

2.3. Calculation of Dustfall Fluxes. Dustfall flux is the mass of dust deposited per unit area per time [26]. The dustfall flux was calculated with the help of the amount of each sample calculated during sampling time using the following equation [27]:

$$
D=\frac{M}{A \times T}
$$


TABLE 1: Geographical comparison of dustfall fluxes.

\begin{tabular}{|c|c|c|c|}
\hline Sampling site & Country & Deposition flux (g/m²/yr) & References \\
\hline \multicolumn{4}{|l|}{ Present study } \\
\hline New Delhi & India & 35.28 & This paper \\
\hline \multicolumn{4}{|l|}{ Other Indian studies } \\
\hline Jharia coal mining (residential site) & India & 116.48 & {$[37]$} \\
\hline Jharia coal mining (commercial site) & India & 168.73 & {$[37]$} \\
\hline \multicolumn{4}{|l|}{ Non-India studies } \\
\hline Northern Nigeria & Africa & 159 & {$[55]$} \\
\hline McMurdo Valley & Antarctica & 0.49 & {$[32]$} \\
\hline Namoi Valley & Australia & 31.4 & {$[56]$} \\
\hline Coast Mountains, BC & Canada & 10.9 & {$[57]$} \\
\hline Guagzhou & China & 45.36 & {$[39]$} \\
\hline Desert regions & China & 450 & {$[58]$} \\
\hline French Alps & France & 2.10 & {$[30]$} \\
\hline South Island & New Zealand & 26.4 & {$[59]$} \\
\hline Miami, Florida & USA & .26 & [31] \\
\hline
\end{tabular}

where $D$ is the deposition flux in gram per square meter per day, $M$ is the mass $(g)$ of the dustfall during each sampling period, $A$ is the area of the tray in square meter, and $T$ is the duration for which the dust was collected.

\subsection{Analysis of Dustfall and Soil Samples}

2.4.1. Mineralogical Analysis. Mineralogy of the dustfall and soil samples was determined by using XRD (Philips X'pert powder diffractometer). Samples sieved through 200 mesh were subjected to XRD analysis. Each sample was kept in the sampling plate of instrument and compacted with the help of a glass slide. Samples were analyzed using an accelerating voltage of $45 \mathrm{kV}$, tube electric flow of $40 \mathrm{~mA}$, scanning speed of $2^{\circ} /$ minute, and scanning step of $0.02^{\circ}$ with the range of $5^{\circ}-$ $50^{\circ}$ (range of $2 \theta$ ). A graph as a result was obtained between intensity (counts) and position ( $2 \theta$ values). Minerals were identified from diffractogram by tallying the $d$-spacing values with that of mineral in the standard library given in the American Society for Testing and Materials (ASTM) powder diffraction data file.

2.4.2. Morphological and Geochemical Analysis of Samples. Dustfall as well as soil samples were prepared in the same manner like XRD. The bulk samples of dust and soil were analyzed for their morphology with Carl Zeiss AG-EVO 40 Series SEM and elemental analysis using energy dispersive spectrometer (EDX). SEM images for each sample were taken at four magnifications namely 500x, 1500x, 3000x, and 6000x. At 1500x, the dimensions of the largest and smallest particles were taken. For EDX analysis, X-ray beam is shot at a particular point from the bulk sample kept on the carbon tape. A graph is obtained between number of counts per channel versus energy in $\mathrm{keV}$. Each peak in the graph represents an element.
2.5. Data Sources. Data were taken from several reports [18, $20,28,29]$ which were essential to correlate our study with LULCC, vehicular expansion, population growth, SPM level, RSPM level, road length, type, and number of industries. In the present study, total number of vehicles, growth of road lengths, and number and types of factories registered [20, 28] have been discussed in relation with dustfall fluxes with its mineralogical and geochemical composition. $\mathrm{NO}_{2}, \mathrm{SPM}$, and respirable suspended particulate matter (RSPM) data were taken from Central Pollution Control Board and Delhi Pollution Control Committee [18, 28, 29]. LULC from 1989 to 2011 were taken from research findings of Mukhopadhyay and coworkers (2013) [18].

\section{Results and Discussion}

3.1. Dustfall Fluxes of Samples. The fluxes of dustfall varied from 13 to $56 \mathrm{~g} / \mathrm{m}^{2} /$ year with an average flux value of $35 \mathrm{~g} / \mathrm{m}^{2} /$ year which translate around $52 \mathrm{Gg}$ of dust deposition every year over $1490 \mathrm{~km}^{2}$ area of Delhi city. These estimates are at lower side for a typical urban site as the JNU site has large green cover representing urban background characteristics. Table 1 provides dustfall flux values from other regions within India and around the world obtained through a comprehensive literature review for comparison. Being a semiarid tropical site, the present study site had relatively higher range of fluxes as compared to the temperate region (Table 1). The dustfall flux at this site was noticed higher than French Alps [30], Miami [31], and McMurdo valley, Antarctica [32]. Such higher fluxes can be attributed to soil resuspension, traffic flow, construction activities, and long range transport of fine dust. The exploding vehicular population of the city might be a reason for higher dustfall fluxes. Vehicle traffic and unpaved area alongside roads increase the resuspension of road dust [33]. Delhi has witnessed a very fast growth in number of 


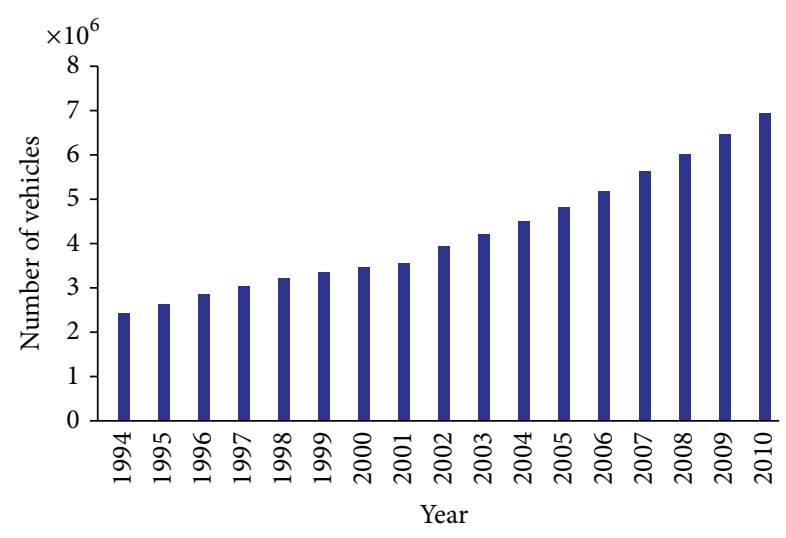

Figure 2: Total number of vehicles during 1994-2010 [20].

vehicles during past two decades. The number of mobile vehicles in Delhi has increased dramatically from 24,32,295 in 1994 to 69,32,706 in 2010 (Figure 2) [20]. However, the road length is not increased at the same rate as the number of vehicles (Figure 3). Though the city has seen an exponential expansion in road length between 1980 and 2002 but in subsequent period as shown in Figure 3, there has been very insignificant hike in road length due to which a surge of vehicles is seen on the roads. Built-up area of Delhi witnessed an overall increase from $540.7 \mathrm{~km}^{2}$ to $791.96 \mathrm{~km}^{2}$ or $16.86 \%$ of the total city area $\left(1490 \mathrm{~km}^{2}\right)$ during the study period 1997 to 2008 which is mainly acquired from agriculture land, waste land, scrubland, sandy areas, and water bodies [17]. The increase in forest cover of $0.5 \%$ between 1989 and 2011 is very small as compared to the increase (17\%) in built-up category [18]. In a ten-year period, total area of water bodies has reduced by $52.9 \%\left(58.26 \mathrm{~km}^{2}\right.$ in 1997 to $27.43 \mathrm{~km}^{2}$ in 2008) with shallow water bodies now having a dismal presence [17]. Due to fast urbanization, LULCC also might be responsible for higher values of dustfall fluxes and particulate matter. LANDSAT TM5 (Thematic Mapper 5) images are shown in Figure 4. The LANDSAT provides global record of the Earth's surface. LANDSAT imageries are very useful for first level of classification of urban land cover. Figure 4 clearly indicates that, as compared to 1989 , fellow land and vegetation cover have drastically decreased in 2011 while built-up area has increased significantly [18] which might lead to higher fluxes of dustfall.

Built-up area is generally an indicator of anthropogenic activities [17]. The combination of reduced area of fellow land and vegetation cover with increased built-up area is mainly responsible for high loadings of suspended dust. Evidently, Figures 5 and 6 show that the values of SPM and RSPM are continuously rising in Delhi due to anthropogenic activities (CPCB, 2012; Economic Survey of India, 2012-13). Due to this reason, most of the time the values of RSPM and SPM are above the permissible limits of NAAQS of CPCB [29, 34]. Open soil and land are mainly responsible for high atmospheric particulate matter in Indian region $[35,36]$.

The fluxes of dustfall of this study were compared with other studies worldwide (Table 1). Rout and coworkers

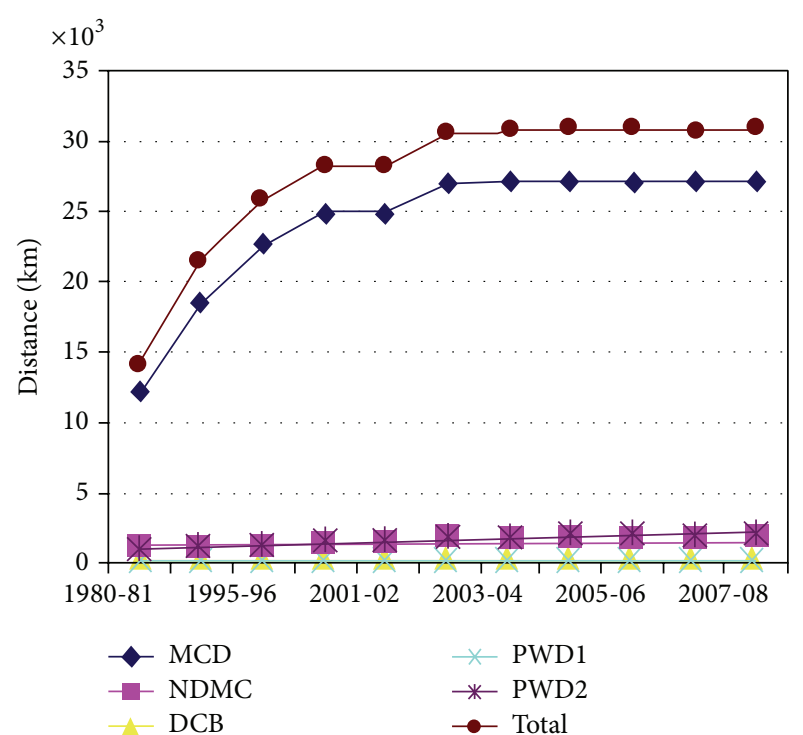

FIGURE 3: Growth of roads in Delhi, MCD = Municipal Corporation of Delhi, NDMC = New Delhi Municipal Committee, DCB = Delhi Cantonment Board, and PWD = Public Works Department [28].

(2014) found that the average dustfall fluxes were higher at commercial site $\left(168.73 \mathrm{~g} / \mathrm{m}^{2} /\right.$ year $)$ than the residential site $\left(116.48 \mathrm{~g} / \mathrm{m}^{2} /\right.$ year) of Jharia coal mining area in Jharkhand, India, which were attributed to dust emissions from the coal handling plant, crushing operations, conveying, loading, and unloading of the coal [37]. In another study by Reheis and Kihl (1995), fluxes of silt and clay content in dustfall in southern Nevada and southeastern California have been reported in the range of 4.3 to $15.7 \mathrm{~g} / \mathrm{m}^{2} / \mathrm{yr}$ [38]. However, same study has reported very high silt and clay fluxes $\left(30 \mathrm{~g} / \mathrm{m}^{2} / \mathrm{yr}\right)$ in southwestern California. Zhao and coworkers (2010) had reported very high dustfall fluxes at Guagzhou, a subtropical city in South China, due to factors such as proximity to a construction site, heavy traffic, and agricultural activities [39].

3.2. Mineralogical Characteristics of Soil and Dust. The mineralogical characteristics of dust samples were obtained by means of X-ray diffraction (XRD) analysis. Figure 7 shows typical X-ray diffractogram of dust and soil samples. Table 2 gives the mineralogical composition with its chemical formula of dust samples. The major minerals found in the dust samples are quartz, muscovite, chlorite, calcite, albite, and dolomite. A few dust samples contained gypsum too. The mineralogical composition of dust might be due to geographical characteristics of soil, land use and land cover pattern, road length, and vehicular flow. Geological map of Delhi city is given in Figure 1. It is clear from the map that Delhi geology consists mainly of sand, silt, and clay with unoxidised sand and quartzite [40]. Thus the dominance of quartz is justified in dust samples. Other parameters which are affecting mineralogy of dust have been discussed in Section 3.1. Dusts rich in mainly quartz, carbonates, and feldspar are usually continental and originate mainly from 

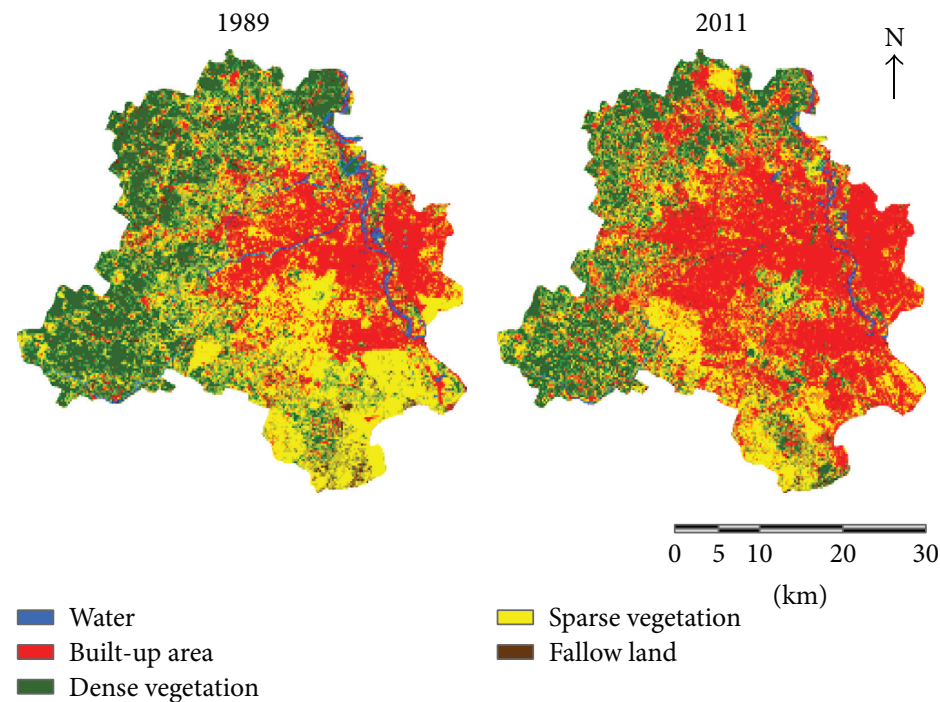

FIgURE 4: Land use land cover (LULC) maps of Delhi 1989 and 2011 [18].

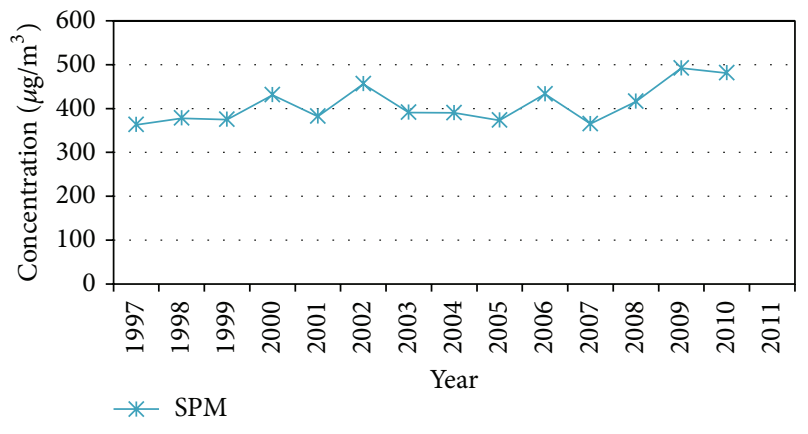

FIgURE 5: SPM levels at Delhi [28].

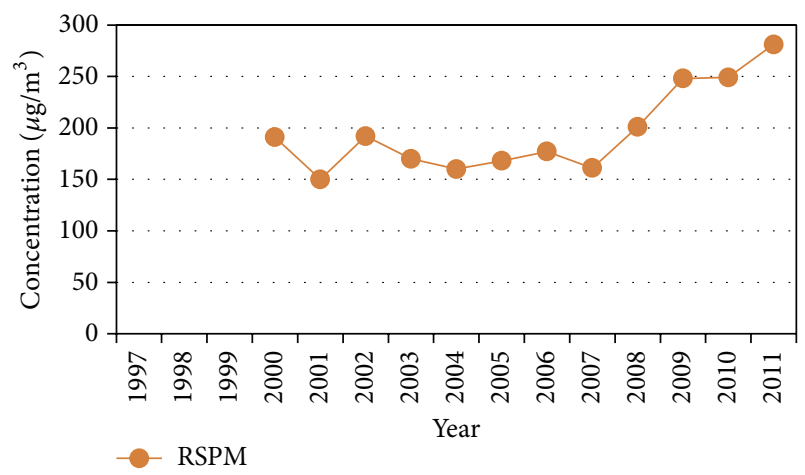

Figure 6: RSPM levels at Delhi [28].

local sources [41]. Abundance of $\mathrm{CaCO}_{3}$ in atmospheric dust has been reported in India by Kulshrestha and coworkers (2003) [21]. High values of suspended particulate matter have been reported in this region due to crustal sources [42]. Presence of Gypsum in atmospheric dust is possibly due to the adsorption of $\mathrm{SO}_{2}$ onto the soil derived $\mathrm{CaCO}_{3}$ particles forming $\mathrm{CaSO}_{4} \cdot 2 \mathrm{H}_{2} \mathrm{O}$ [43]. Yadav and Rajamani
TABle 2: Percent occurrence of mineralogical composition of dust and soil samples $(+=$ present, $-=$ absent $)$.

\begin{tabular}{llcc}
\hline Minerals & Chemical formula & Dustfall & Soil \\
\hline Quartz & $\mathrm{SiO}_{2}$ & + & + \\
Muscovite & $\mathrm{KAl}_{2}\left(\mathrm{Si}_{3} \mathrm{Al}\right) \mathrm{O}_{10}(\mathrm{OH}, \mathrm{F})_{2}$ & + & + \\
Chlorite & $\left(\mathrm{Mg}_{5} \mathrm{Al}\right)\left(\mathrm{AlSi}_{3}\right) \mathrm{O}_{10}(\mathrm{OH})_{8}$ & + & + \\
Calcite & $\mathrm{CaCO}_{3}$ & + & + \\
Albite (low) & $\mathrm{NaAlSi}_{3} \mathrm{O}_{8}$ & + & + \\
Dolomite & $\left.\mathrm{CaMg}_{(\mathrm{CO}}\right)_{2}$ & - & + \\
Actinolite & $\mathrm{Ca}_{2}(\mathrm{Mg}, \mathrm{Fe}++)_{5} \mathrm{Si}_{8} \mathrm{O}_{22}(\mathrm{OH})_{2}$ & - & + \\
Oligoclase & $(\mathrm{Na}, \mathrm{Ca})(\mathrm{Si}, \mathrm{Al})_{4} \mathrm{O}_{8}$ & - & + \\
Gypsum & $\mathrm{CaSO} \cdot 2\left(\mathrm{H}_{2} \mathrm{O}\right)$ & + & - \\
\hline
\end{tabular}

(2006) have reported the dominance of quartz followed by $\mathrm{K}$-feldspar, mica, calcite, chlorite, and plagioclase in aerosol samples at northwestern part of India adjoining Thar Desert [44]. Microprobe data in the same study also revealed the presence of biotite, amphibole, garnet, titanite, and zircon. They observed that chemistry of atmospheric aerosol is affected predominantly by upper continental crust influence. Similarly, dusts from Jharia mining area in eastern Jharkhand were found to be dominated by kaolinite, pyrite, albite, and magnesiohornblende [37].

Furthermore, mineralogical composition of soil dust provides important information about the region, possible human health effects, and radiative forcing implications [45]. It also influences the acidification potential of rainwater and various aquatic bodies. More alkaline materials have buffering effect against acidification $[21,46]$. Due to this reason, soil samples were also analyzed for mineralogical contents. The mineralogical composition of soil samples showed that the major part of all the samples contained quartz, muscovite, and chlorite. The mineralogical composition of dustfall and soil was compared at the site. The mineralogical composition of the dustfall and soil differed significantly. It was observed 


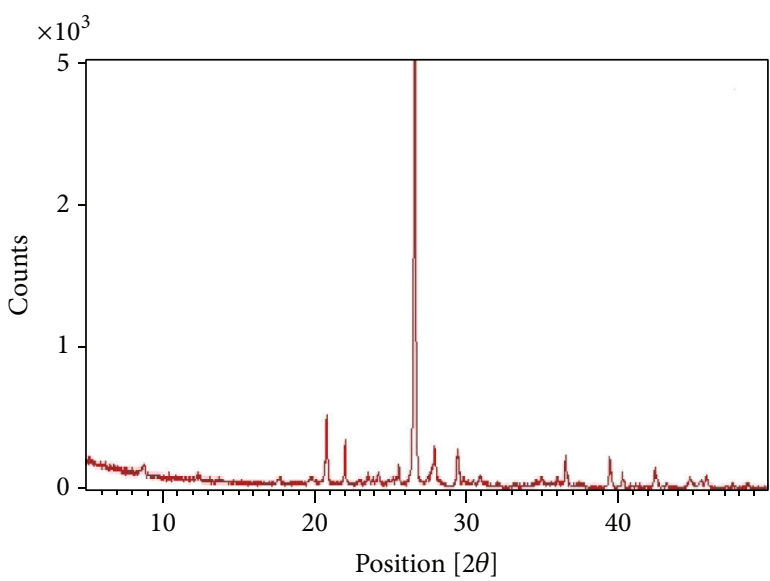

(a)

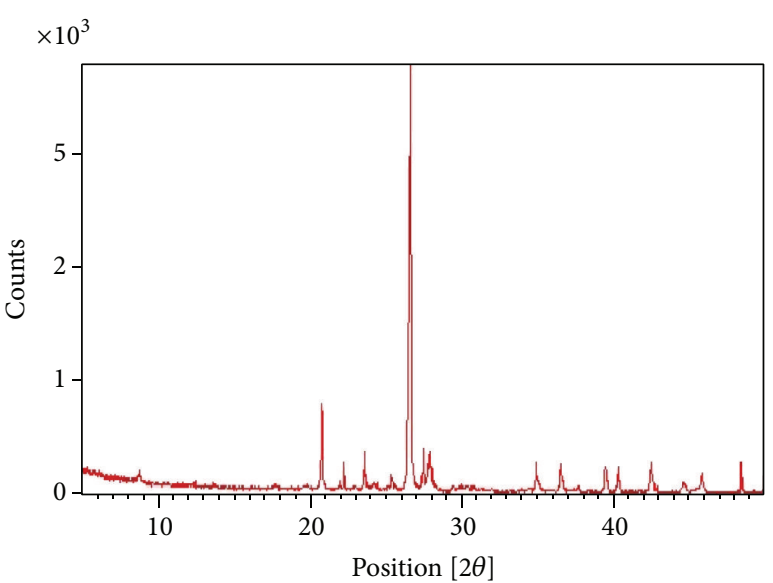

(b)

FIGURE 7: X-ray diffractogram of dust (a) and soil (b) samples.

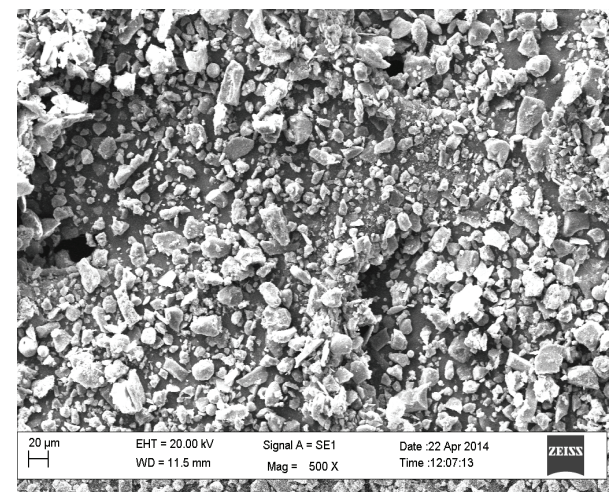

(a) Dust sample: 500x

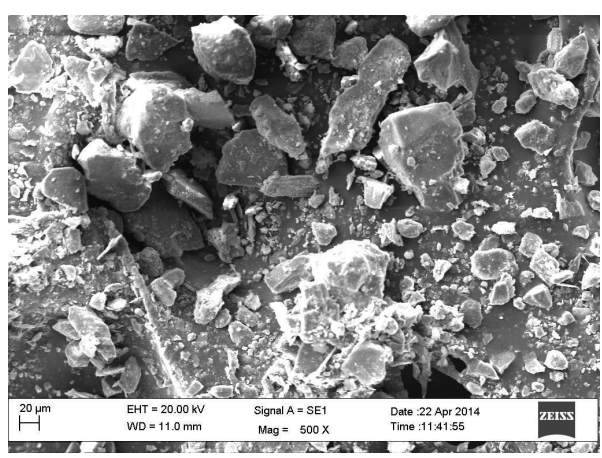

(c) Soil sample: $500 \mathrm{x}$

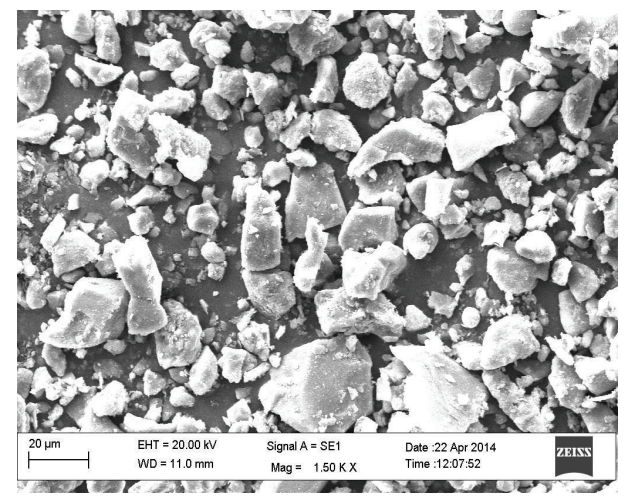

(b) Dust sample: 1500x

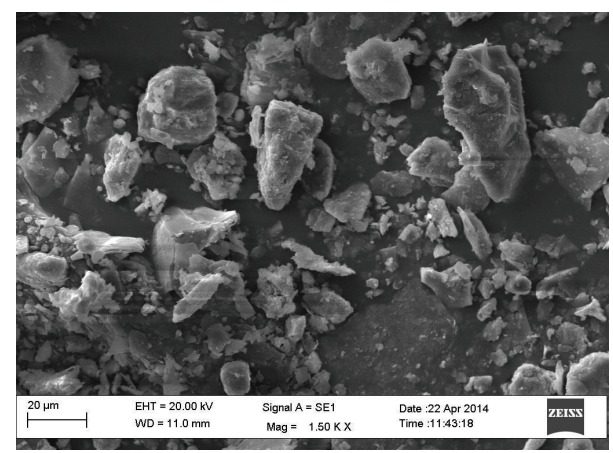

(d) Soil sample: $1500 \mathrm{x}$

FIGURE 8: (a)-(d): SEM images of dust and soil samples at magnifications 500x and 1500x.

that quartz, muscovite, and chlorite are present as major minerals in dust and soil samples. If we consider dust and soil having the same origin, it must have the same mineralogical composition but the observed difference suggested that chemical characteristics of suspended soil were significantly modified in the atmosphere as the dust particles interacted with atmospheric pollution [47]. Influence of local as well as transported gaseous and particulate pollutants has resulted in significant transformation in atmospheric dust.
3.3. Morphological Analyses of Soil and Dust. Morphological assessment of the dust samples was carried out by using SEM. Images of one dust and local soil sample with two magnifications (500x and 1500x) are shown in Figure 8 (a to d). It is clear from the figures that the dust sample was dominated by spherical, irregular, tubular, long and prismatic, porous, crystalline, and rhombic twining shape of particles. The various shapes of the particles in dust samples might be due to various sources, geological characteristics, traffic 


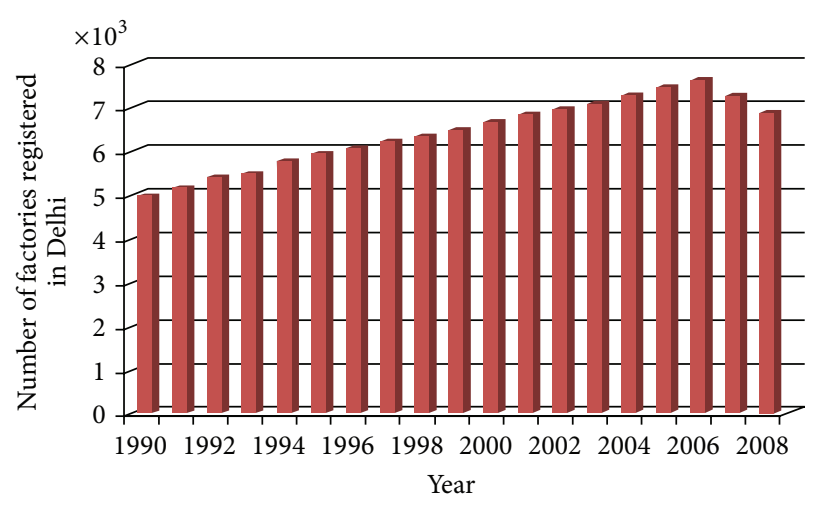

FIGURE 9: Number of factories registered in Delhi, 1990-2008 [28].

flow, land use and land cover pattern, and meteorological parameters. It has been reported that regional geology and wind direction are the controller of the mineralogy and morphology of airborne dusts [48]. Similar to our results, Pachauri and coworkers (2013) found variable morphology in different size ranges of individual coarse particles in Agra, India [49]. These workers have reported that tubular shape was due to presence of silica while irregular and spherical shapes were because of the biological particles [49].

The shapes of the particles varied from tubular structure of silica to irregular shape of biological particles [49]. Aluminosilicates and chain like aggregates of soot were attributed to spherical to triangular and from rectangular to irregular shapes. Pipal and coworkers (2011) also reported that chain-like agglomerations might be due to the presence of carbonaceous material such as soot [50]. The presence of soot particles may be due to emissions from vehicular traffic, thermal power plants, and other industrial units located in and around Delhi. Figure 9 shows the number of registered industrial units in Delhi while number of vehicles can be read from Figure 2. The presence of chain-like agglomerations soot particles at residential and commercial site was attributed to domestic coal burning and biomass burning by Rout and coworkers (2014) [37]. Zhao and coworkers (2010) found that the irregular granular aggregates were marker of construction dust and normal granular were markers of road dust [39]. Chain aggregates and spherical particles were considered from industrial smoke dust. The difference observed in shape of dust and soil particle in this study might be due to interaction of suspended soil with various atmospheric pollutants. This has further implication to radiative forcing, climate change, human health, cloud formation, and so forth.

3.4. Elemental Composition of Soil and Dust. Figure 10 illustrates elemental composition of soil and dust samples. In order to highlight the fraction contributed by other elements, oxygen has not been included in the pies. However, oxygen content has been mentioned separately on the respective pie. These pies clearly show that fraction contributed by carbon and calcium in dust is significantly higher than that of soil. However, silica fraction dominated in soil samples. Similar

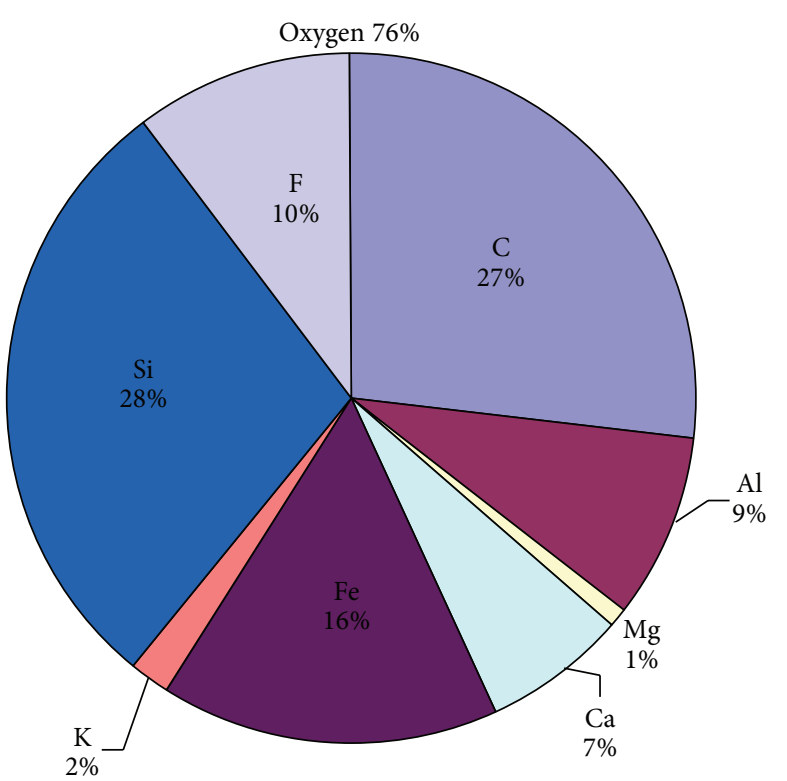

(a)

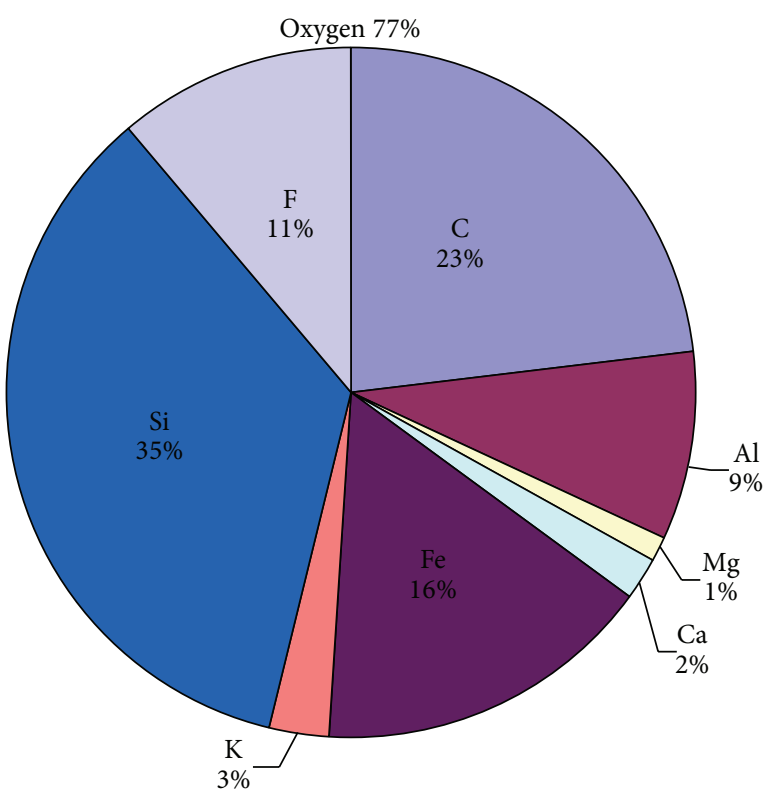

(b)

FIgURE 10: Average elemental composition of dust and soil samples (excluding oxygen \%).

observation has been reported by Kulshrestha and coworkers (2012) where suspended particles have been found enriched with carbon as compared with local soil [51]. Figure 11 shows the comparison of elements in dust and soil samples. While in suspension, the dust components have greater possibility to interact with various air pollutants allowing adsorption of gases and other particulates including carbonaceous aerosols. The mineralogy determined by EDX supported these observations too. The soil sample had the presence of $\mathrm{Si}(8.21 \%)$, $\mathrm{C}$ (5.37\%), $\mathrm{Al}$ (2.08\%), $\mathrm{Mg}$ (0.28\%), Ca (0.45\%), Fe (3.8\%), and $\mathrm{K}(0.61 \%)$. The dust sample showed $\mathrm{Si}(7.06 \%), \mathrm{C}(6.59 \%)$, 
TABLE 3: Industry wise registered factories in Delhi, 2007-2011 [28].

\begin{tabular}{|c|c|c|c|c|c|c|}
\hline \multirow{2}{*}{ S. number } & \multirow{2}{*}{ Type of industries } & \multicolumn{5}{|c|}{ Factories } \\
\hline & & 2007 & 2008 & 2009 & 2010 & 2011 \\
\hline 1 & Food product & 250 & 253 & 262 & 274 & 285 \\
\hline 2 & Beverages, tobacco, and tobacco products & 32 & 33 & 33 & 36 & 38 \\
\hline 3 & Textiles products & 1869 & 1886 & 1901 & 1918 & 1931 \\
\hline 4 & Wood products, furniture, and fixtures & 254 & 247 & 250 & 254 & 256 \\
\hline 5 & $\begin{array}{l}\text { Paper and paper products, printing publishing and } \\
\text { allied }\end{array}$ & 628 & 646 & 651 & 674 & 682 \\
\hline 6 & Leather and leather fur products (except repair) & 266 & 269 & 270 & 272 & 279 \\
\hline 7 & Rubber, plastic, petroleum coal products & 524 & 528 & 528 & 537 & 557 \\
\hline 8 & $\begin{array}{l}\text { Chemical and chemical products (except petroleum } \\
\text { and coal) }\end{array}$ & 288 & 295 & 296 & 297 & 293 \\
\hline 9 & Nonmetallic mineral products & 77 & 79 & 79 & 79 & 80 \\
\hline 10 & Basic metal and alloy industry & 517 & 522 & 530 & 525 & 524 \\
\hline 11 & $\begin{array}{l}\text { Metal products and parts machinery and transport } \\
\text { equipments-machine tools including electrical and } \\
\text { supply }\end{array}$ & 1692 & 1723 & 1735 & 1757 & 1759 \\
\hline 12 & Electricity gas and stream water works and supply & 73 & 83 & 84 & 94 & 102 \\
\hline 13 & $\begin{array}{l}\text { Wholesale trade in fuel, chemicals, perfumery, } \\
\text { ceramics, and glass }\end{array}$ & 10 & 10 & 15 & 7 & 12 \\
\hline 14 & Public administration and defense services & 1 & 1 & 2 & 2 & 2 \\
\hline 15 & Sanitary services & 6 & 6 & 6 & 6 & 10 \\
\hline 16 & Repair of capital goods and repair services & 422 & 439 & 452 & 465 & 470 \\
\hline \multirow[t]{2}{*}{17} & Miscellaneous unspecified group & 893 & 901 & 903 & 912 & 930 \\
\hline & Total & 7802 & 7921 & 7997 & 8109 & 8219 \\
\hline
\end{tabular}

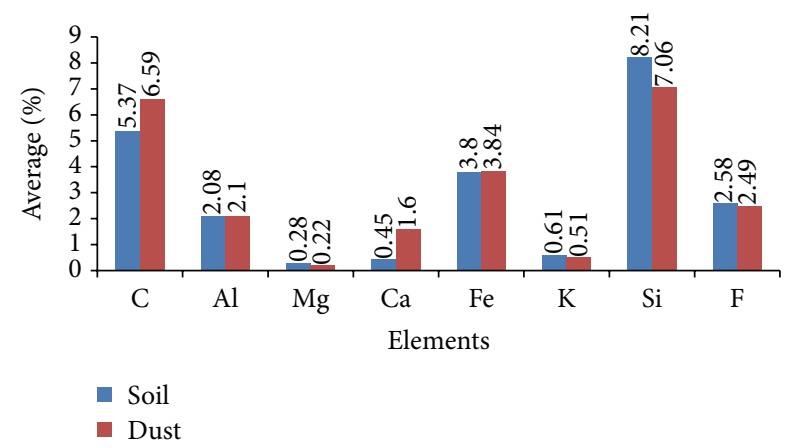

FIGURE 11: Elemental composition of soil and dust samples (excluding oxygen).

$\mathrm{Al}(2.1 \%), \mathrm{Mg}(0.22 \%), \mathrm{Ca}(1.6 \%), \mathrm{Fe}(3.84 \%)$, and $\mathrm{K}(0.51 \%)$. These results indicated that the dust had more carbon content due to various combustion sources. Relatively higher fraction of $\mathrm{Ca}$ in dust is probably due to mixed contributions from soil, road dust, and construction activities [43]. Similarly, $\mathrm{Fe}, \mathrm{K}$, and $\mathrm{Mg}$ are contributed by crustal sources. Similar to our results, Bhattacharjee and coworkers also found the dominance of Si in soil samples [52]. Zhang and coworkers (2010) have reported that Si was contributing $44.3 \%$ and $38.7 \%$ for dusty and nondusty cases, respectively [53].

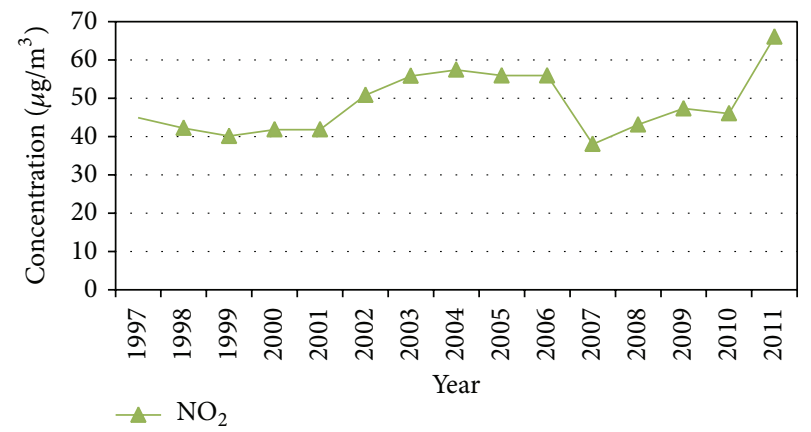

FIgURE 12: $\mathrm{NO}_{2}$ levels at Delhi [28].

Delhi has witnessed an exponential growth in population which is almost proportional to the demand of land use for urbanization [20]. Also, this has led to the increase in fuel consumption. The sale of petrol as fuel has risen from $550,000 \mathrm{M}$ tons to $800,000 \mathrm{M}$ tons in a span of 10 years from 2001 to 2010 [20] sharing an increase of over $63 \%$ in consumption of petrol. Due to increase in vehicular growth, road length, and construction activities, SPM and RSPM levels have crossed NAAQS [29] (Figures 5 and 6). This is witnessed by the increasing levels of $\mathrm{NO}_{2}$ due to huge growth of vehicles in Delhi [28] as shown in Figure 12. Similarly, the sale of LPG is also increased by almost 50\% from 2001 to 2010 [20]. 
Table 3 gives the list of different types of industries in Delhi [28]. The huge growth of industries might be one of the possible reasons for higher $\mathrm{C}$ content in dust samples as compared to soil. Around 39\% growth is recorded in the industrial units during 1994 to 2011 in Delhi region [20]. Similarly, as mentioned earlier, higher concentration of $\mathrm{Ca}$ can be attributed to the increase in road length, vehicular expansion, and construction activities.

\section{Conclusion}

The findings of study may be summarized as follows.

(1) Around $52 \mathrm{Gg}$ of atmospheric dust is deposited in Delhi city every year.

(2) LANDSAT images show a drastic change in LULCC in Delhi during past two decades. Decreasing green cover and built-up area of Delhi contribute high fluxes of dustfall. Interaction of soil dusts with various air pollution species results in more harmful nature of atmospheric dust.

(3) Soil is dominated by silica but the atmospheric dust has significantly high fraction of carbon soot. Carbon rich dust could have serious impact on human health, global warming, visibility, radiative forcing, monsoon, and so forth.

(4) The dustfall fluxes are significantly higher than the value reported for temperate regions because of dry weather conditions of Delhi region which support higher rate of soil erosion and the suspension of soil into the atmosphere.

(5) If the present rate of urbanization and industrialization continued, the size of green cover of the city will be reduced in order to meet increasing demand of housing, transport, and industrial sectors.

\section{Conflict of Interests}

The authors declare that there is no conflict of interests regarding the publication of this paper.

\section{Acknowledgments}

The authors sincerely thank financial support received from JNU as CBF, LRE, and DST-PURSE grants which helped them to carry out this work. Author Bablu Kumar acknowledges the award of Junior Research Fellowship from UGC.

\section{References}

[1] IUPAC, "Glossary of atmospheric chemistry terms. International Union of Pure and Applied Chemistry, Applied Chemistry Division, Commission on Atmospheric Chemistry," Pure and Applied Chemistry, vol. 62, no. 11, pp. 2167-2219, 1990.

[2] H. Maring, D. L. Savoie, M. A. Izaguirre, L. Custals, and J. S. Reid, "Mineral dust aerosol size distribution change during atmospheric transport," Journal of Geophysical Research, vol. 108, no. 19, 2003, 10.1029/2002JD002536.
[3] N. J. Middleton and A. S. Goudie, "Saharan dust: sources and trajectories," Transactions of the Institute of British Geographers, vol. 26, no. 2, pp. 165-181, 2001.

[4] T. D. Jickells, Z. S. An, K. K. Andersen et al., "Global iron connections between desert dust, ocean biogeochemistry, and climate," Science, vol. 308, no. 5718, pp. 67-71, 2005.

[5] I. Tegen and I. Fung, "Modeling of mineral dust in the atmosphere: sources, transport, and optical thickness," Journal of Geophysical Research, vol. 99, no. 11, pp. 22897-22914, 1994.

[6] I. Tegen and I. Fung, "Contribution to the atmospheric mineral aerosol load from land surface modification," Journal of Geophysical Research, vol. 100, pp. 18707-18726, 1995.

[7] W. Ta, H. Xiao, J. Qu et al., "Measurements of dust deposition in Gansu Province, China, 1986-2000," Geomorphology, vol. 57, no. 1-2, pp. 41-51, 2004.

[8] M. O. Andreae and P. J. Crutzen, "Atmospheric aerosols: biogeochemical sources and role in atmospheric chemistry," Science, vol. 276, no. 5315, pp. 1052-1058, 1997.

[9] U. C. Kulshrestha, L. A. K. Reddy, J. Satyanarayana, and M. J. Kulshrestha, "Real-time wet scavenging of major chemical constituents of aerosols and role of rain intensity in Indian region," Atmospheric Environment, vol. 43, no. 32, pp. 5123-5127, 2009.

[10] R. J. Charlson, S. E. Schwartz, J. M. Hales et al., "Climate forcing by anthropogenic aerosols," Science, vol. 255, no. 5043, pp. 423430, 1992.

[11] M. O. Andreae, E. Atlas, H. Cachier et al., "Trace gas and aerosol emissions from savanna fires," in Biomass Burning and Global Change, J. S. Levine, Ed., pp. 278-295, MIT Press, Cambridge, Mass, USA, 1996.

[12] F. J. Dentener, G. R. Carmichael, Y. Zhang, J. Lelieveld, and P. J. Crutzen, "Role of mineral aerosol as a reactive surface in the global troposphere," Journal of Geophysical Research: Atmospheres, vol. 101, no. D17, pp. 22869-22889, 1996.

[13] C. R. Lawrence and J. C. Neff, "The contemporary physical and chemical flux of aeolian dust: a synthesis of direct measurements of dust deposition," Chemical Geology, vol. 267, no. 1-2, pp. 46-63, 2009 .

[14] W. W. Wood and W. E. Sanford, "Chemical and isotopic methods for quantifying ground-water recharge in a regional, semiarid environment," Ground Water, vol. 33, pp. 458-468, 1995.

[15] F. J. Larney, J. F. Leys, J. F. Müller, and G. H. McTainsh, "Dust and endosulfan deposition in a cotton-growing area of Northern New South Wales, Australia," Journal of Environmental Quality, vol. 28, no. 2, pp. 692-701, 1999.

[16] P. J. Lioy, C. P. Weisel, J. R. Millette et al., "Characterization of the dust/smoke aerosol that settled east of the World Trade Center (WTC) in lower Manhattan after collapse of the WTC 11 September 2001," Environmental Health Perspectives, vol. 110, no. 7, pp. 703-714, 2002.

[17] M. Mohan, S. K. Pathan, K. Narendrareddy, A. Kandya, and S. Pandey, "Dynamics of urbanization and its impact on landuse/land-cover: a case study of megacity Delhi," Journal of Environmental Protection, vol. 2, pp. 1274-1283, 2011.

[18] A. Mukhopadhyay, S. Mukherjee, R. D. Garg, and T. Ghosh, "Spatio-temporal analysis of land use-land cover changes in Delhi using remote sensing and GIS techniques," International Journal of Geomatics and Geosciences, vol. 4, no. 1, pp. 213-223, 2013. 
[19] M. Punia, P. K. Joshi, and M. C. Porwal, "Decision tree classification of land use land cover for Delhi, India using IRSP6 AWiFS data," Expert Systems with Applications, vol. 38, no. 5, pp. 5577-5583, 2011.

[20] DSHB, Delhi Statistical Hand Book 2009-2011, Directorate of Economics and Statistics Government of National Capital Territory of Delhi, 2011, http://www.delhi.gov.in/wps/wcm/ connect/doit_des/DES/Our+Services/Statistical+Hand+Book/.

[21] M. J. Kulshrestha, U. C. Kulshrestha, D. C. Parashar, and M. Vairamani, "Estimation of $\mathrm{SO}_{4}$ contribution by dry deposition of $\mathrm{SO}_{2}$ onto the dust particles in India," Atmospheric Environment, vol. 37, no. 22, pp. 3057-3063, 2003.

[22] H. Rodhe, J. Galloway, and Z. Dianwu, "Acidification in southeast Asia: prospects for the coming decades," Ambio, vol. 21, no. 2, pp. 148-150, 1992.

[23] "WHO Air quality guidelines for particulate matter, ozone, nitrogen dioxide and sulfur dioxide, Global update 2005, Summary of risk assessment," http://whqlibdoc.who.int/hq/ 2006/WHO_SDE_PHE_OEH_06.02_eng.pdf.

[24] M. S. Krishnan, Geology of India and Burma, CBS Publishers, Delhi, India, 6th edition, 1982.

[25] F. Ahmad and Z. S. Ahmad, "The fan faults of peninsular India and the origin of the Himalayas," Tectonophysics, vol. 64, no. 1-2, pp. 97-110, 1980.

[26] C. I. Davidson and Y. L. Wu, "Dry deposition of particles and vapors," in Acidic Precipitation, S. E. Lindberg, A. L. Page, and S. A. J. Norton, Eds., vol. 3, Springer, New York, NY, USA, 1989.

[27] M. Katz, Measurement of Air Pollutants-Guide to Selection of Methods, World Health Organization, Geneva, Switzerland, 1969.

[28] Economic survey of India, Energy and transport section, http://delhi.gov.in.

[29] CPCB, "Annual report " Ministry of Environment \& forests, Government of India, 2012, http://cpcb.nic.in/National_Ambient_Air_Quality_Standards.php.

[30] M. De Angelis and A. Gaudichet, "Saharan dust deposition over Mont Blanc (French Alps) during the last 30 years," Tellus B, vol. 43, no. 1, pp. 61-75, 1991.

[31] J. M. Prospero, R. T. Nees, and M. Uematsu, "Deposition rate of particulate and dissolved aluminum derived from Saharan dust in precipitation at Miami, Florida," Journal of Geophysical Research-Atmospheres, vol. 92, no. D12, pp. 14723-14731, 1987.

[32] N. Lancaster, "Flux of eolian sediment in the McMurdo Dry Valleys, Antarctica: a preliminary assessment," Arctic, Antarctic, and Alpine Research, vol. 34, no. 3, pp. 318-323, 2002.

[33] F. Amato, M. Pandolfi, M. Viana, X. Querol, A. Alastuey, and T. Moreno, "Spatial and chemical patterns of $\mathrm{PM}_{10}$ in road dust deposited in urban environment," Atmospheric Environment, vol. 43, no. 9, pp. 1650-1659, 2009.

[34] U. C. Kulshrestha, "Biomass burning and atmospheric dust: issue of regional significance for climate change in south Asia," in Proceedings of the International Conference on Climate and Sustainable Management of Natural Resources, ITM University, Gwalior, India, February 2014.

[35] L. T. Khemani, G. A. Momin, P. S. Prakasa Rao, P. D. Safai, G. Singh, and R. K. Kapoor, "Spread of acid rain over India," Atmospheric Environment, vol. 23, no. 4, pp. 757-762, 1989.

[36] U. C. Kulshrestha, M. Jain, R. Sekar, M. Vairamani, A. K. Sarkar, and D. C. Parashar, "Chemical characteristics and source apportionment of aerosols over Indian ocean during INDOEX," Current Science, vol. 80, pp. 180-185, 1999.
[37] T. K. Rout, R. E. Masto, P. K. Padhy, J. George, L. C. Ram, and S. Maity, "Dust fall and elemental flux in a coal mining area," PII: S0375-6742(14)00135-6, 2014.

[38] M. C. Reheis and R. Kihl, "Dust deposition in southern Nevada and California, 1984-1989: relations to climate, source area, and source lithology," Journal of Geophysical Research, vol. 100, no. 5, pp. 8893-8918, 1995.

[39] X. P. Zhao, A. Ackerman, and W. Guo, "Dust and smoke detection for multi-channel imagers," Remote Sensing, vol. 2, no. 10, pp. 2347-2368, 2010.

[40] I. A. Parvez, F. Vaccari, and G. F. Panza, "Site-specific microzonation study in Delhi Metropolitan City by 2-D modelling of SH and P-SV waves," Pure and Applied Geophysics, vol. 161, no. 5-6, pp. 1165-1184, 2004.

[41] K. Pye, Aeolian Dust and Dust Deposits, Academic Press, San Diego, Calif, USA, 1987.

[42] U. C. Kulshrestha, N. Kumar, and A. Saxena, "Chemical composition of atmospheric aerosol at three representative sites at Agra," Energy Environment Monitor, vol. 11, pp. 177-181, 1995.

[43] U. C. Kulshrestha, "Acid rain," in Encyclopedia of Environmental Management, Taylor \& Francis, Manila Typesetting Company, 2013.

[44] S. Yadav and V. Rajamani, "Air quality and trace metal chemistry of different size fractions of aerosols in N-NW Indiaimplications for source diversity," Atmospheric Environment, vol. 40, no. 4, pp. 698-712, 2006.

[45] A. Rashki, D. G. Kaskaoutis, A. S. Goudie, and R. A. Kahn, "Dryness of ephemeral lakes and consequences for dust activity: the case of the Hamoun drainage basin, Southeastern Iran," Science of the Total Environment, vol. 463-464, pp. 552-564, 2013.

[46] H. Rodhe, F. Dentener, and M. Schulz, "The global distribution of acidifying wet deposition," Environmental Science and Technology, vol. 36, no. 20, pp. 4382-4388, 2002.

[47] F. J. Dentener, G. R. Carmichael, Y. Zhang, J. Lelieveld, and P. J. Crutzen, "Role of mineral aerosol as a reactive surface in the global troposphere," Journal of Geophysical Research D: Atmospheres, vol. 101, no. 17, pp. 22869-22889, 1996.

[48] A. Zarasvandi, E. J. M. Carranza, F. Moore, and F. Rastmanesh, "Spatio-temporal occurrences and mineralogical-geochemical characteristics of airborne dusts in Khuzestan Province (southwestern Iran)," Journal of Geochemical Exploration, vol. 111, no. 3, pp. 138-151, 2011.

[49] T. Pachauri, V. Singla, A. Satsangi, A. Lakhani, and K. Maharaj Kumari, "SEM-EDX characterization of individual coarse particles in Agra, India," Aerosol and Air Quality Research, vol. 13, no. 2, pp. 523-536, 2013.

[50] A. S. Pipal, A. Kulshrestha, and A. Taneja, "Characterization and morphological analysis of airborne $\mathrm{PM}_{2.5}$ and PM10 in Agra located in north central India," Atmospheric Environment, vol. 45 , no. 21, pp. 3621-3630, 2011.

[51] U. C. Kulshrestha, B. Kumar, G. P. Gupta, S. Singh, and M. J. Kulshrestha, "Defining criteria for good habitats: importance of bioaerosols, black, carbon and trace gases," Indian Journal of Air Pollution Control, vol. 7, pp. 24-30, 2012.

[52] A. Bhattacharjee, H. Mandal, M. Roy, J. Kusz, M. Zubko, and P. Gütlich, "Microstructural and magnetic characterization of dusts from a stone crushing industry in Birbhum, India," Journal of Magnetism and Magnetic Materials, vol. 322, no. 22, pp. 3724-3727, 2010. 
[53] R. Zhang, Z. Shen, T. Cheng, M. Zhang, and Y. Liu, “The elemental composition of atmospheric particles at Beijing during Asian dust events in spring 2004," Aerosol and Air Quality Research, vol. 10, no. 1, pp. 67-75, 2010.

[54] C. Hanumantharao and G. V. Ramana, "Dynamic soil properties for microzonation of Delhi, India," Journal of Earth System Science, vol. 117, no. 2, pp. 719-730, 2008.

[55] G. H. McTainsh and P. H. Walker, "Nature and distribution of Harmattan dust," Zeitschrift fur Geomorphologie, vol. 26, no. 4, pp. 417-435, 1982.

[56] S. R. Cattle, G. H. McTainsh, and S. Wagner, “Æolian dust contributions to soil of the Namoi Valley, northern NSW, Australia," Catena, vol. 47, no. 3, pp. 245-264, 2002.

[57] P. N. Owens and O. Slaymaker, "Contemporary and post-glacial rates of aeolian deposition in the Coast Mountains of British Columbia, Canada," Geografiska Annaler A: Physical Geography, vol. 79, no. 4, pp. 267-276, 1997.

[58] X. Y. Zhang, R. Arimoto, G. H. Zhu, T. Chen, and G. Y. Zhang, "Concentration, size-distribution and deposition of mineral aerosol over Chinese desert regions," Tellus B: Chemical and Physical Meteorology, vol. 50, no. 4, pp. 317-330, 1998.

[59] S. K. Marx and H. A. McGowan, "Dust transportation and deposition in a superhumid environment, West Coast, South Island, New Zealand," Catena, vol. 59, no. 2, pp. 147-171, 2005. 

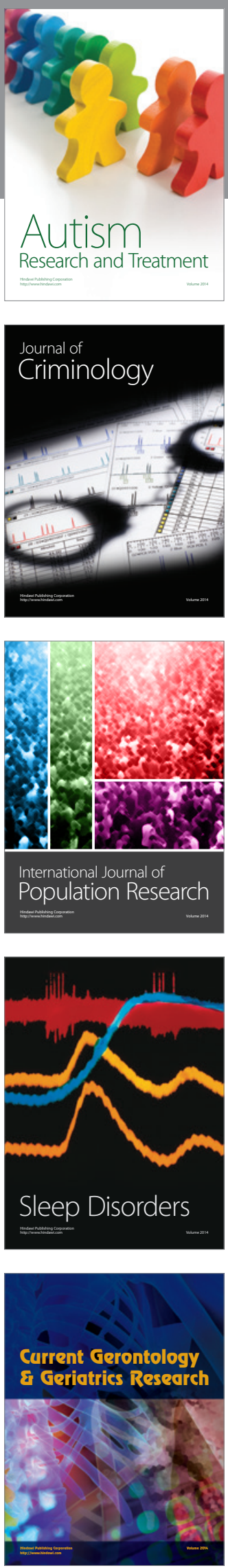
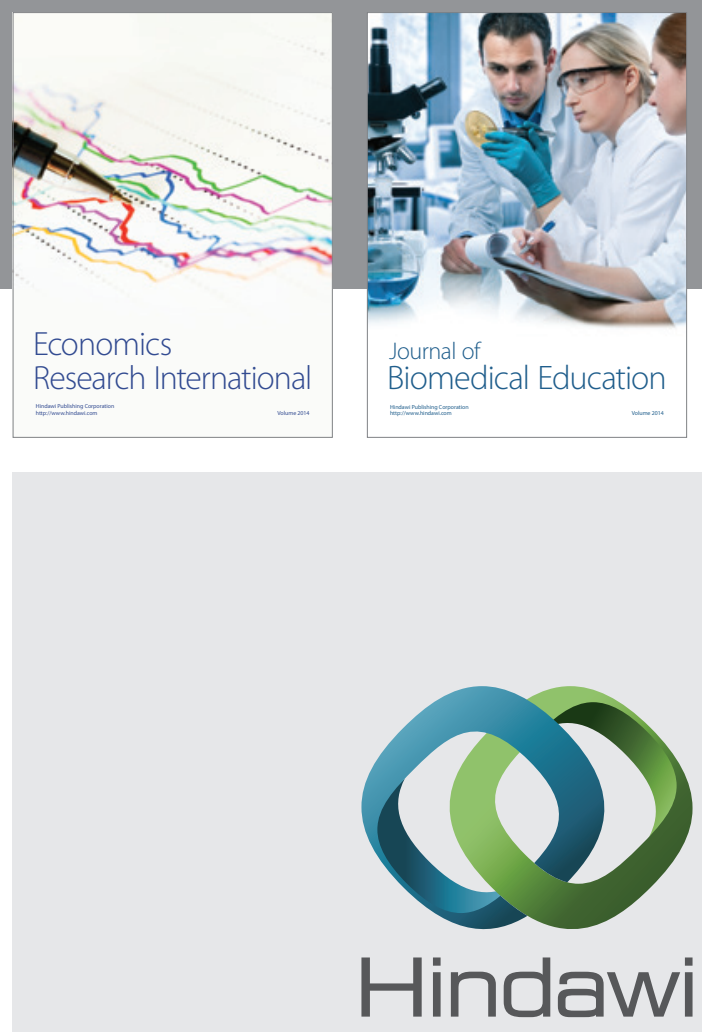

Submit your manuscripts at

http://www.hindawi.com
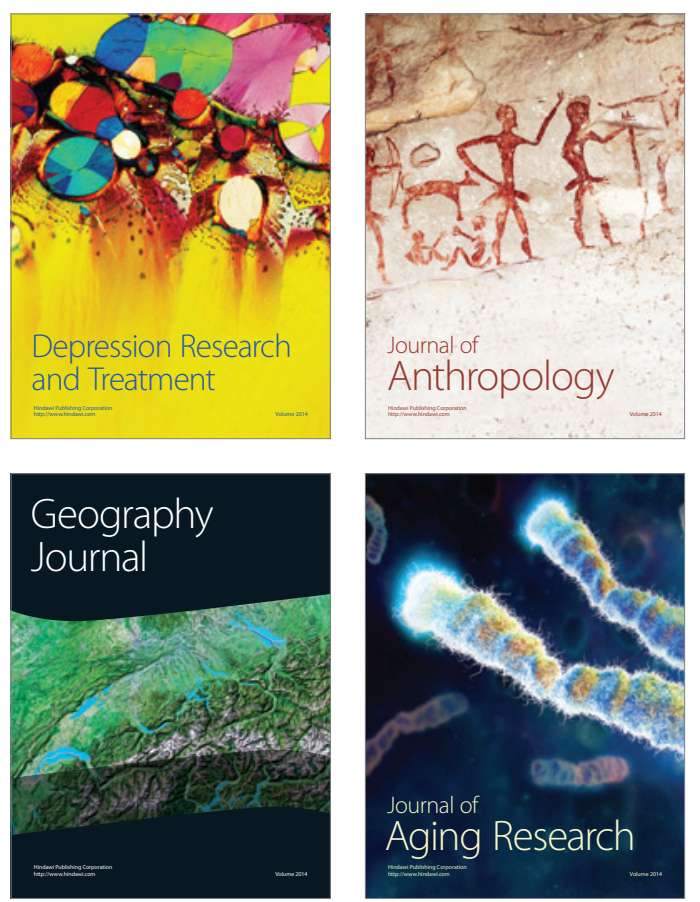
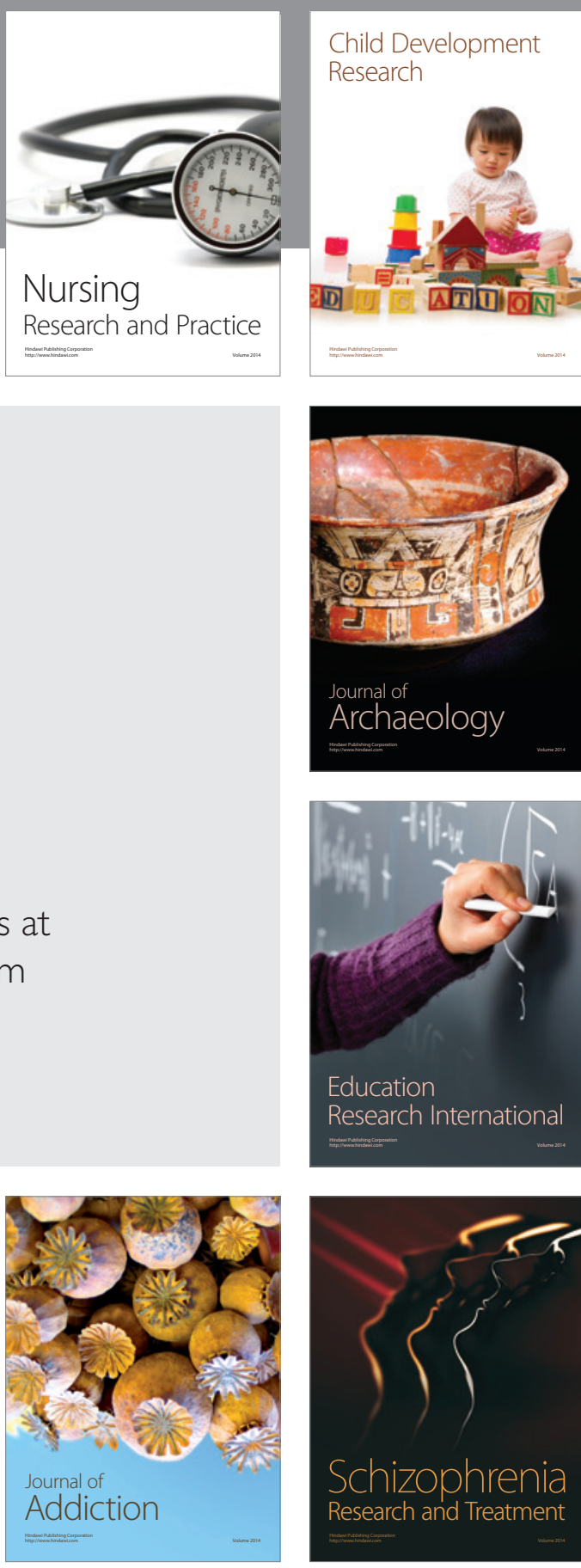

(D)
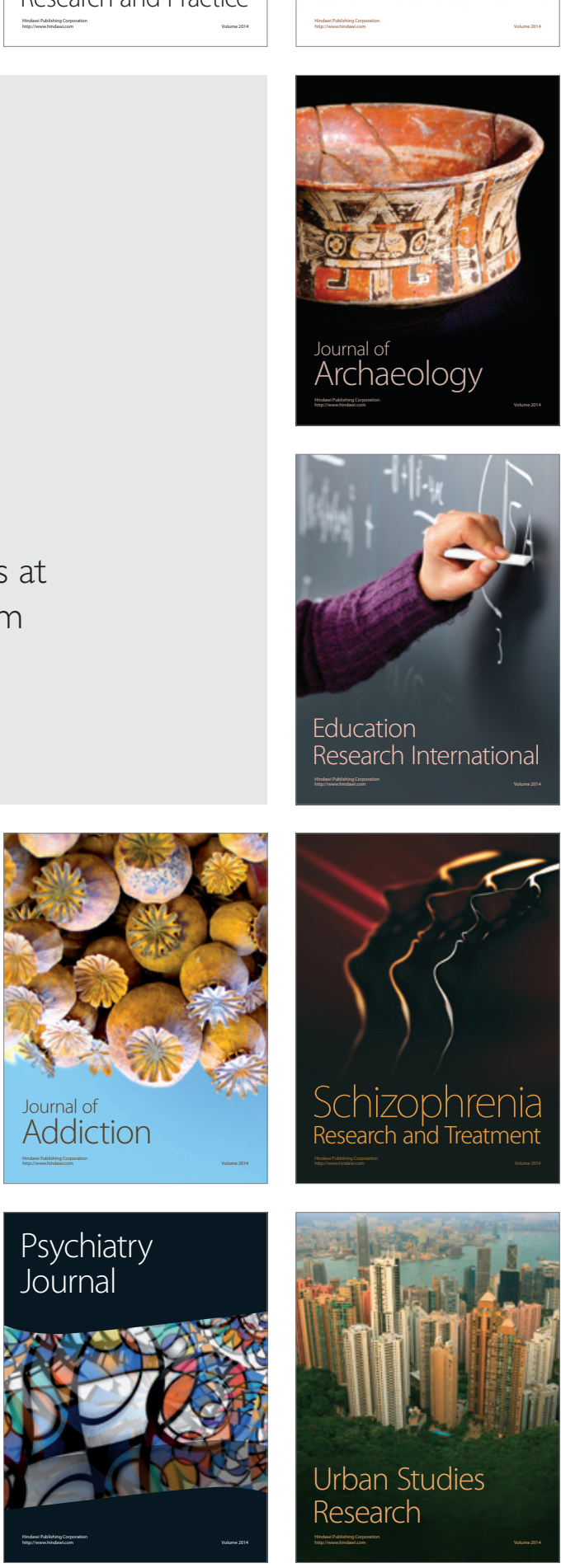